\title{
Augmented Reality Untuk Sistem Pernafasan Pada Manusia
}

\author{
Eka Larasati Amalia ${ }^{a}$, Dhebys Suryani H. ${ }^{b}$ \\ ${ }^{\mathrm{a}, \mathrm{b}}$ Politeknik Negeri Malang, Soekarno Hatta No 09, Malang, Indonesia \\ a,beka.larasati@polinema.ac.id, dhebys.suryani@polinema.ac.id
}

\begin{abstract}
Teknologi maju dengan cepat karena banyak hal yang tidak mungkin beberapa tahun yang lalu menjadi mungkin sekarang. Augmented Reality adalah sintetis, realitas simulasi komputer atau rekreasi dari lingkungan waktu-nyata di mana pengguna dapat berinteraksi dengan lingkungan nyata yang direplikasi. Biologi hanya diajarkan dengan cara konvensional melalui buku sehingga membuat siswa hanya memperhatikan teks dan gambar. Untuk menarik minat mereka, pelajaran akan menjadi lebih menarik dan interaktif jika siswa dapat melihat proses secara langsung dalam bentuk 3D sebagai itu membuat siswa menghafalkannya dengan nyaman. Sistem pernapasan dan sirkulasi darah adalah contoh dari Biologi untuk kelas dua SMP. Dengan menerapkan Augmented Reality, mereka dapat mengambil pelajaran secara interaktif melalui objek digital dalam kenyataan. Desain Augmented Reality dalam sistem pernapasan dan sirkulasi darah untuk siswa SMP dibuat dengan aplikasi Blender. Pembuatan aplikasi AR dengan platform android menggunakan kesatuan engine game. Berdasarkan uji fungsional yang dilakukan oleh para peneliti, dapat disimpulkan bahwa dengan menerapkan aplikasi tersebut, pengguna dapat memperoleh informasi terkait sistem pernapasan dan sirkulasi darah manusia yang dapat disampaikan secara menarik dan interaktif kepada para siswa.
\end{abstract}

Kata Kunci-Pernafasan manusia, sirkulasi darah manusia, Augmented Reality

\section{PENDAhUluan}

Di era globalisasi ini, perkembangan teknologi informasi dan komunikasi telah menjangkiti publik, seiring berjalannya waktu. Augmented Reality Berkembang sangat pesat sehingga memungkinkan pengembangan aplikasi ini di berbagai bidang termasuk pendidikan. Augmented Reality adalah upaya untuk menggabungkan dunia nyata dan dunia virtual yang dibuat melalui komputer sehingga batas antara keduanya menjadi sangat tipis. Keuntungan dari metode Augmented Reality ini adalah tampilan visual yang menarik dan dapat menampilkan objek 3D yang tampaknya ada di lingkungan nyata. Augmented Reality juga memiliki keuntungan interaktif karena menggunakan spidol untuk menampilkan objek 3D tertentu yang diarahkan ke kamera. Selain itu, penerapan konsep yang akan digunakan diharapkan dapat meningkatkan penalaran dan imajinasi siswa [2].

Berdasarkan hal di atas, maka perlu menjadikan sistem pernapasan dan sirkulasi darah manusia berbasis Android sebagai media pembelajaran. Android memungkinkan siswa untuk belajar kapan saja dan di mana saja dengan mudah, tetapi masih mengacu pada buku teks. Sehingga memudahkan pemahaman siswa dalam mempelajari mata pelajaran biologi.

\section{TINJAUAN PUSTAKA}

\subsection{Sistem Pernafasan dan Peredaran Darah}

Bernafas adalah proses memasukkan oksigen ke dalam alat pernapasan dan menghilangkan karbon dioksida dan uap air. Ada 2 jenis pernapasan pada manusia, yaitu inspirasi dan kadaluarsa. Mekanisme pernapasan manusia adalah pernapasan dada dan pernapasan perut. Pernapasan dada adalah pernapasan yang menggunakan tulang rusuk tulang dada, tulang rusuk diangkat sehingga rongga dada membesar. Sedangkan pernapasan perut adalah bernafas menggunakan diafragma. Alat bantu pernapasan manusia adalah hidung, faring, trakea, bronkus dan bronkiolus, paru-paru, dan alveolus.

Bagi para ilmuwan biologi, bernapas adalah seluruh proses sel dalam suatu organisme dalam menerima oksigen dan melepaskan karbon dioksida. Pernapasan dapat dibagi menjadi tiga bentuk, pernapasan eksternal, pernapasan internal, dan pernapasan seluler [4]. Agar proses pernapasan bisa terjadi, peralatan pernapasan sangat dibutuhkan. Alat-alat ini berurutan dimulai dari hidung, faring, laring, trakea dan paru-paru. 


\subsection{Android}

Android dipuji sebagai Platform Seluler lengkap pertama, sumber terbuka, dan gratis (Platform Lengkap). Di mana desainer dapat mengambil pendekatan komprehensif ketika mereka sedang mengembangkan platform Android. Android adalah sistem operasi yang aman dan menyediakan banyak alat dalam membangun perangkat lunak dan memungkinkan peluang pengembangan aplikasi. Open Source Platform, platform android yang disediakan melalui lisensi open source. Pengembangan dapat dengan bebas mengembangkan aplikasi. Gratis (Free Platform), di mana android adalah platform atau aplikasi yang bebas untuk dikembangkan. Tidak ada lisensi atau biaya royalti untuk dikembangkan di platform Android. Tidak ada biaya keanggotaan, dan biaya pengujian. Tidak ada kontrak yang diperlukan. Aplikasi android ini dapat didistribusikan dan diperdagangkan dalam bentuk apa pun [5].

\subsection{Augmented Reality}

Augmented Reality memiliki metode kerja sederhana berdasarkan deteksi gambar dan biasanya disebut penanda. Misalnya, kamera yang telah dikalibrasi dapat mendeteksi marker yang telah dirancang, kemudian setelah mendeteksi marker, kamera akan cocok dengan database yang telah dibuat sebelumnya. Dan jika hasilnya cocok, maka informasi dari marker akan digunakan untuk menampilkan objek 3D yang telah dirancang di depan layar pengguna, tetapi jika marker tidak cocok dengan database maka informasi dari marker tidak akan diproses [6].

Augmented Reality (AR) adalah teknologi yang melibatkan gambar grafik komputer dengan dunia nyata. Pengguna dapat melihat dunia nyata plus objek virtual dan dapat berinteraksi dengan lingkungan nyata. Dalam konteks yang lebih umum, AR juga disebut Mixed Reality yang mengacu pada spektrum multisumbu yang mencakup Virtual Reality (VR), Augmented Reality (AR), dan teknologi lainnya [7].

\subsection{Unity}

Unity adalah alat terintegrasi untuk membuat game, membangun arsitektur, dan simulasi. Unity tidak dirancang untuk proses desain atau pemodelan, karena Unity bukan alat untuk mendesain. Jika Anda ingin mendesain, gunakan editor 3D lain seperti 3dsmax atau Blender. Banyak hal yang dapat dilakukan dengan Unity, ada fitur zona reverb audio, efek partikel, dan kotak langit untuk menambahkan langit.

\subsection{Vuforia}

Menurut situs resmi Vuforia (vuforia.com) Vuforia adalah Perangkat Pengembangan Perangkat Lunak Augmented Reality (SDK) untuk seluler yang memungkinkan pembuatan aplikasi Augmented Reality. Sebelumnya lebih dikenal sebagai QCAR (Qualcomm Company Augmented Reality). Ini menggunakan teknologi Computer Vision untuk mengenali dan merencanakan gambar (Gambar Target) dan objek 3D sederhana, seperti kotak, secara real-time. Kemampuan registrasi gambar memungkinkan pengembang menyesuaikan posisi dan orientasi virtual objek, seperti 3D, model dan media lain dengan gambar dunia nyata ketika ini terlihat melalui kamera dari objek virtual perangkat mobile kemudian melacak posisi dan orientasi gambar secara real-time sehingga perspektif pengguna pada objek sesuai dengan persepsi mereka Gambar Target, sehingga tampak bahwa objek virtual adalah bagian dari adegan dunia nyata.

\section{PEMBAHASAN}

\subsection{Gambaran Umum Sistem}

Arsitektur aplikasi ini adalah sistem yang akan melibatkan pengguna yang menggunakan perangkat smartphone Android. Pengguna menggunakan selebaran sistem pernapasan dan sirkulasi darah manusia sebagai gambar target atau penanda yang disesuaikan. Marker diletakkan di depan kamera, maka kamera akan menangkap spidol dan menampilkan objek pada layar smartphone. Gambaran umum dari sistem yang ditunjukkan pada Gambar 1.

\subsection{Spesifikasi Aplikasi}

Spesifikasi Dalam fase analisis mengenai spesifikasi persyaratan perangkat lunak yang diperlukan dalam penerapan Augmented Reality Pernafasan Manusia untuk Siswa Sekolah Menengah adalah:
a. Sebuah. Windows 7
b. Blender 2.77
c. Adobe Photoshop CS 6
d. Unity 5.6 


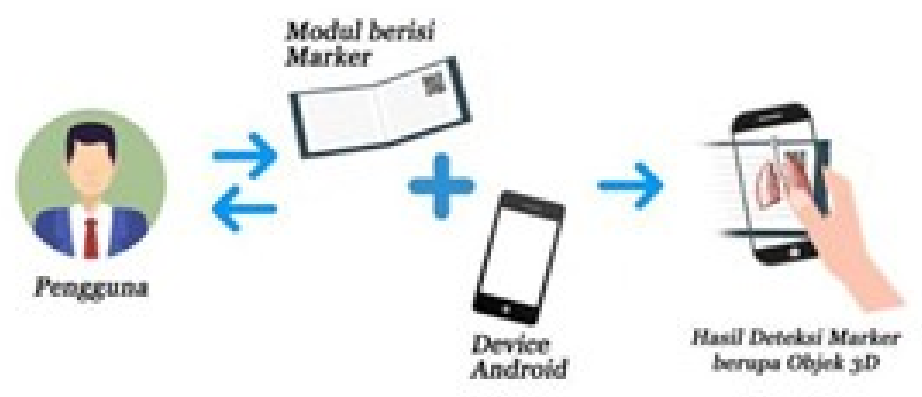

\subsection{Storyboard}

Gambar 1. Gambaran Umum Sistem

Storyboard digunakan pada tahap desain dalam menjalankan aplikasi. Dapat dijelaskan pada tabel berikut 1 .

Tabel 1. Story board

Informasi
Pengguna menggunakan perangkat
smartphone Android aplikasi AR telah
diinstal dan selebaran sistem pernapasan
dan sirkulasi darah manusia sebagai
target gambar atau penanda yang telah
disesuaikan.

\section{IMPLEMENTASI}

\subsection{Membuat Objek Organ Alveolus}

Berikut ini adalah tampilan pemodelan organ alveolar di paru-paru. Langkah pertama adalah mesh dengan subdivisi 1 untuk model avelous seperti yang ditunjukkan pada Gambar 2. 


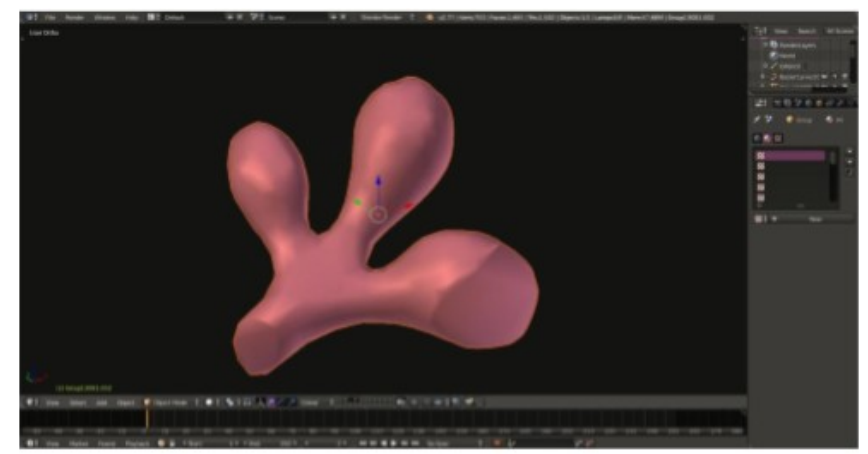

Gambar 2. Objek Organ Alveolus

Kemudian buat saluran alvelous seperti yang ditunjukkan pada Gambar 3.

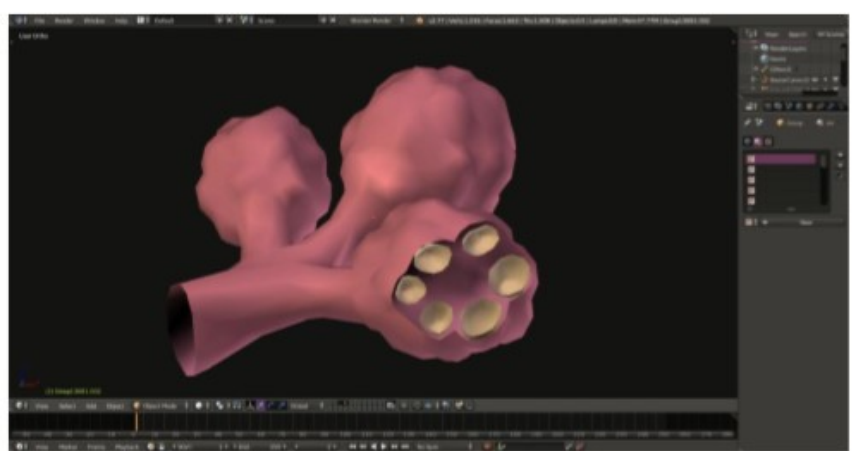

Gambar 3. Saluran Alveolar

\subsection{Membuat Marker Pada Augmented Reality}

Dalam membuat teknik untuk Augmented Reality, AR Camera akan mendeteksi penanda, sehingga objek yang diatur dapat muncul di layar. Gambar 4. adalah gambar yang digunakan untuk menjadi penanda pada aplikasi ini.

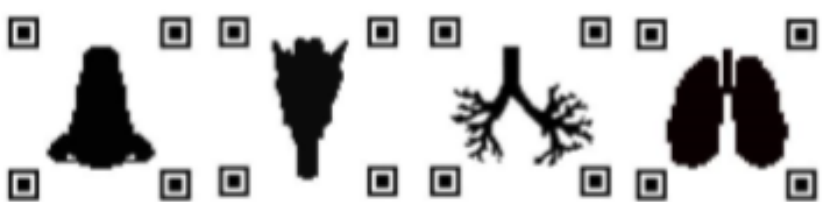

Gambar 4. Marker yang Digunakan dalam Aplikasi

Gambar marker dibuat menggunakan perangkat lunak Adobe Photoshop. Dapat dilihat pada setiap marker yang mewakili setiap objek 3D yang telah dibuat sebelumnya. Sebenarnya dalam Vuforia marker berbagai bentuk dan warna dapat dikenali, tetapi untuk membuatnya lebih mudah dibaca oleh AR Camera, marker dengan dua warna dipilih, yaitu hitam dan putih.

\subsection{Implementasi Animasi 3D Hidung}

Organ-organ tampilan halaman organ-organ hidung 3D ditunjukkan pada Gambar 5. pada menu organ hidung menampilkan proses ketika oksigen melewati hidung. 


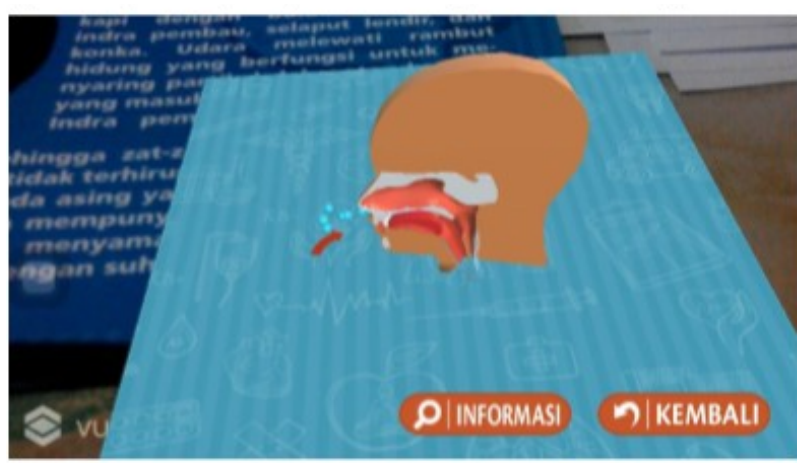

Gambar 5. Implementasi Animasi 3D Hidung

\subsection{Implementasi Animasi 3D dari Faring dan Trakea}

Organ Tampilan faring dan trakea Halaman organ 3D ditunjukkan pada Gambar 6. pada menu organ faring dan trakea menampilkan proses ketika oksigen melewati faring ke trakea.

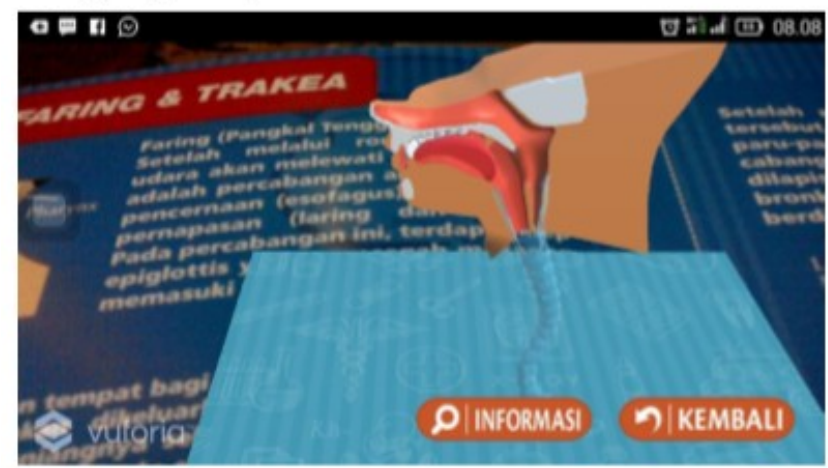

Gambar 6. Implementasi Animasi 3D Faring dan Trakea

\section{KESIMPULAN}

Kesimpulan dari hasil tes adalah sebagai berikut.

1. Aplikasi Myrespi dapat memodelkan organ Sistem Pernafasan dan Peredaran Manusia dalam bentuk animasi 3 dimensi yang dibuat dengan aplikasi blender, sehingga membuatnya lebih mudah untuk memahami subjek biologis tentang sistem pernapasan dan sirkulasi darah untuk siswa kelas 8 SMP.

2. Aplikasi ini dapat menjadi media pembelajaran yang menarik bagi siswa. Berdasarkan kuesioner, responden memberikan tanggapan bahwa aplikasi ini membantu meningkatkan minat belajar siswa.

\section{ACKNOWLEDGMENT}

Penulis mengucapkan terima kasih kepada Politeknik Negeri Malang yang telah mendukung proyek penelitian ini.

\section{REFERENCES}

[1] Pearce, C. Evelyn.2006.Anatomi dan Fisiologi untuk Paramedic. Jakarta : Penerbit PT Gramedia Pustaka Utama

[2] Januanesbi, Galan.2014.Pembelajaran Vulkanologi Secara 3D Berbasis augmented Reality. Universitas Muhammadiyah Surakarta. Skripsi Tidak Diterbitkan.

[3] Matrix, Tim.2009.Seri Panduan Belajar dan Evaluasi Biologi untuk SPM/MTs kelas VIII. Jakarta : Grasindo,

[4] P, Fictor Ferdinand dan Ariebowo, Moekti.2009.Praktis Belajar Biologi 2 (IPA). [Online] Tersedia http://bse.annibuku.com/buku/871/praktis-belajarbiologi-2-ipa [21 Januari 2017]

[5] Safaat, Nazruddin.2012.Pemrograman Aplikasi Mobile Smartphone dan Tablet Berbasis Android.Bandung : INFORMATIKA

[6] RistyAmmatia.2012. Augmented Reality Paper. [Online] Tersedia http://images.ammatiaristy.multiply.multiplycontent.com/attachment [12 Januari 2017]

[7] Toan Phan, Viet dan Yeon Choo, Seung.2010.Interior Design in Augmented Reality Environment. [Online] Tersedia http://www.ijcaonline.org [12 Januari 2017]

[8] Unity Technologies.Pengertian Unity. [Online] Tersedia http://unity3d.com/unity [15 Januari 2017]

[9] Boediman Surja, Andi.1995.Photoshop Special F/X. Jakarta: PT. Elex Media Komputindo. 